\title{
HUBUNGAN PENDAMPINGAN SUAMI TERHADAP TINGKAT KECEMASAN IBU BERSALIN DI RB CITRA PALEMBANG TAHUN 2018
}

\author{
Meta Rosdiana \\ Program Studi D III Kebidanan STIK Siti Khadijah Palembang \\ J1. Demang Lebar Daun Lorok Pakjo Palembang 30137 \\ Email :rosdiana.meta76@gmail.com
}

\begin{abstract}
Abstrak
Ketidaksiapan menghadapi proses persalinan akan menimbulkan rasa takut dan cemas pada ibu. Kecemasan yang dialami oleh ibu bersalin semakin lama akan semakin meningkat seiring dengan semakin seringnya kontraksi muncul sehingga keadaan ini akan membuat ibu semakin tidak kooperatif. Kehadiran suami atau pasangan sangat dianjurkan untuk mendampingi ibu selama persalinan karena pendekatan langsung dapat mendorong komunikasi diantara keduanya sehingga dapat mengatasi semua kekhawatiran. Tujuan penelitian ini adalah diketahuinya hubungan pendampingan suami terhadap tingkat kecemasan ibu bersalin di Rumah Bersalin Citra Palembang Tahun 2018. Penelitian ini menggunakan pendekatan Cross Sectional. Sampel berjumlah 28 responden diambil dengan teknik Accidental Sampling. Dari hasil uji Chi-Square diperoleh $p$ value $(0,030)<(0,05)$ yang artinya ada hubungan yang bermakna antara pendampingan suami pada ibu bersalin dengan tingkat kecemasan ibu bersalin. Pendampingan suami berhubungan dengan tingkat kecemasan ibu saat bersalin sehingga diharapkan persalinan dengan pendampingan suami menjadi lancar dan terjadinya komplikasi akibat cemas dapat diminimalkan.
\end{abstract}

Kata Kunci $\quad$ : Pendampingan suami, Tingkat kecemasan dan Persalinan normal.

\begin{abstract}
Unpreparedness in the process of labor will cause fear and anxiety for the mother. The longer anxiety that is prolonged by pregnant mothers will be increased alongside the frequency of contractions that appears in such circumstances and it would make the mother less cooperative. Thepresence of husbandsorlover partnersis to accompany his wife during labor process, it is because the direct approach can support apleasant communication between them sothey can overcome all fear sthat matters. Theaimof this study was to know the relationship of husband's assistan cymaternalanxiety level at Rumah Bersalin Citra Palembang in 2018. This method of this study was cross sectional approach. The total number of the sample was 28 respondents, the accidental sampling method was used to select the sample. From ChiSquare test results obtained $p$ value $(0,030)<(0,05)$ which means there is a meaningful relationship between husband's assisting mother with maternal maternal anxiety level. Counseling husband on the wife's birth process associated with the level of anxiety during the wife's maternity is expected to be accompanied by the accompaniment of the husband's smoothly and the occurrence of complications due to anxiety can be minimized.
\end{abstract}

Key words $\quad$ : Husbands' assistance, anxiety levels, normal maternal 


\section{PENDAHULUAN}

Persalinan merupakan proses alamiah yang harus dilewati oleh setiap wanita hamil. Disini peran petugas kesehatan adalah memantau persalinan untuk mendeteksi adanya komplikasi, disamping memberikan bantuan dan dukungan kepada ibu bersalin, tidak sedikit ibu bersalin dan bayi mengalami trauma karena penanganan yang kurang baik. (Saifuddin, 2009)

Dalam sebuah studi dari 280 wanita primigravida di USA pada trimester ketiga ditemukan 193 (68,9\%) wanita memiliki ketakutan yang sangat kuat terhadap proses persalinan sedangkan swedia dari 162 wanita terdapat $97(59,8 \%)$ wanita yang ditemukan mengalami kecemasan dalam menghadapi proses persalinan. (Maitrayani, 2013)

Berdasarkan penelitian yang dilakukan oleh Sodiqoh, 2014 dari Fakultas Kesehatan Masyarakat UNAIR pada tahun 2014 didapatkan hasil pada kelompok responden primigravida mengalami tingkat kecemasan ringan sebanyak 6orang $(27,3 \%)$, tingkat kecemasan berat sebanyak 6 orang $(27,3 \%)$, dan tingkat kecemasan sedang sebanyak 10 orang $(45,4 \%)$. Sedangkan pada kelompok responden multigravida mengalami tingkat kecemasan berat sebanyak 2 orang $(9,5 \%)$, tingkat kecemasan sedang sebanyak 4 orang $(19,0 \%)$, dan tingkat kecemasan ringan sebanyak 15 orang $(71,4 \%)$

Pendampingan suami saat persalinan mempunyai peranan penting bagi ibu karena dapat mempengaruhi psikologis ibu. Kondisi psikologis yang nyaman, rileks dan tenang dapat terbentuk melalui dukungan kasih saying keluarga (Rohma, 2010)

Adapun beberapa hal yang dapat dilakukan ibu untuk menanggulangi masalah kecemasan yang dialami oleh dirinya sendiri yaitu: Kontrol Pernafasan yang Baik, Melakukan Relaksasi, Intervensi Kognitif, Pendekatan Agama, Dukungan Keluarga, Olahraga (Agustinus,2011).

Keberadaan seorang pendamping
sangat dibutuhkan untuk mendampingi
seorang ibu dalam memandu persalinan.

Tugas seorang pendamping adalah memberi dukungan selama kehamilan, persalinan dan nifas, sehingga mempermudah jalannya proses persalinan (Marmi, 2012). Dukungan yang dapat diberikan oleh seorang suami berupa motivasi terhadap istri secara fisik dan psikologis. Dukungan yang diberikan dapat membuat ibu yang mengalami proses persalinan merasa aman dan nyaman (Adnyawati, dkk. 2012).

Tingkat kecemasan wanita selama persalinan akan meningkat jika ia tidak memahami apa yang terjadi pada dirinya. Perasaan cemas, takut, dan nyeri akan membuat wanita tidak tenang menghadapi persalinan, dapat menyebabkan rasa sakit pada waktu persalinan dan akan mengganggu jalannya persalinan, ibu akan menjadi lelah dan kekuatan hilang. Hal ini dapat menyebabkan terjadi proses persalinan yang lama atau biasa disebut dengan partus macet/partus tidak maju yang dapat membahayakan keselamatan ibu dan bayinya (Mochtar, 2007).

Dalam MPS (Making Pregnancy Safer) dinyatakan pendekatan dalam meningkatkan partisipasi suami dalam kesehatan reproduksi adalah membekali suami dengan informasi dan mengikutsertakan suami dalam setiap upaya meningkatan kesehatan reproduksi. Salah satu kegiatan yang dapat dilakukan suami dalam upaya peningkatan kesehatan ibu dan anak adalah mendampingi istri selama proses persalinan dan mendukung upaya rujukan bila diperlukan. (Dep Kes.,2008)

\section{METODE PENELITIAN}

Jenis penelitian ini adalah survei analitik, dengan pendekatan Cross Sectional, dimana variabel independen dan variabel dependen diobservasi sekaligus pada saat yang sama, sedangkan survey analitik dimaksudkan untuk menganalisis hubungan antara variabel dependen dan variabel independen. Populasi dalam penelitian ini adalah semua ibu yang bersalin di Rumah 
Bersalin Citra Palembang pada bulan Januari - Mei tahun 2018 dengan jumlah 188 orang dengan rata-rata jumlah 38 orang perbulan. Sampel dalam penelitian ini adalah sebagian ibu yang melakukan persalinan di Rumah Bersalin Citra Palembang Tahun 2018 pada bulan Juni - Juli Tahun 2018. Pengambilan sampel pada penelitian ini menggunakan teknik Accidental Sampling.

Dalam analisis data pada penelitian ini menggunakan uji signifikansi yang bertujuan untuk mengetahui keeratan hubungan antara variabel digunakan uji korelasi chi square dengan kemaknaan $\alpha=0,05$, kemudian dianalisis dengan bantuan perhitungan komputer SPSS for windows. Bila didapatkan $\rho<\alpha$ maka H0 ditolak artinya ada hubungan antara pendampingan suami dengan tingkat kecemasan ibu bersalin.

\section{HASIL DAN PEMBAHASAN}

1) Karakteristik Responden Berdasarkan Pendampingan Suami.

Tabel 1.

Distribusi Frekuensi Responden Berdasarkan Pendampingan Suami Pada Ibu Bersalin Di RB Citra Palembang Tahun 2018

\begin{tabular}{cccc}
\hline No & $\begin{array}{c}\text { Pendampingan } \\
\text { Suami }\end{array}$ & Jumlah & Persentase \\
\hline \multirow{2}{*}{$\begin{array}{l}\text { Didampingi } \\
\text { Tidak }\end{array}$} & 20 & 71,4 \\
\hline & $\begin{array}{c}\text { didampingi } \\
\text { Jumlah }\end{array}$ & 8 & 28,6 \\
\hline
\end{tabular}

Dari tabel diatas, dapat diketahui pendampingan suami pada ibu bersalin yang didampingi suami yaitu sebanyak 20 responden $(71,4 \%)$ sedangkan yang tidak didampingan suami yaitu sebanyak 8 responden $(28,6 \%)$.
Tabel 2.

Distribusi Frekuensi Responden Berdasarkan Tingkat Kecemasan Ibu Bersalin Di RB Citra Palembang Tahun 2018

\begin{tabular}{|c|c|c|c|}
\hline $\begin{array}{l}\mathbf{N} \\
\mathbf{O} .\end{array}$ & $\begin{array}{c}\text { Tingkat } \\
\text { Kecemasan } \\
\text { Ibu Bersalin }\end{array}$ & Jumlah & Persentase \\
\hline 1. & $\begin{array}{l}\text { Tidak Ada } \\
\text { Kecemasan }\end{array}$ & 7 & 25,0 \\
\hline 2 & $\begin{array}{l}\text { Kecemasan } \\
\text { Ringan }\end{array}$ & 17 & 60,7 \\
\hline 3 & $\begin{array}{l}\text { Kecemasan } \\
\text { Sedang }\end{array}$ & 4 & 14,3 \\
\hline & $\begin{array}{l}\text { Kecemasan } \\
\text { Berat }\end{array}$ & 0 & 0 \\
\hline & Jumlah & 28 & 100,0 \\
\hline
\end{tabular}

Dari tabel 2 diatas, dapat diketahui dari tingkat kecemasan ibu bersalin yang tidak mengalami kecemasan 7 responden $(25,0 \%)$, kecemasan ringan 17 responden $(60,7 \%)$ kecemasan sedang 4 responden $(14,3 \%)$, sedangkan yang mengalami kecemasan berat tidak ada.

3) Hubungan pendampingan suami pada ibu bersalin terhadap tingkat kecemasan ibu bersalin.

2) Karakteristik Responden

Berdasarkan Tingkat Kecemasan

Ibu Bersalin. 
Tabel 3.

\section{Distribusi Frekuensi Pendampingan Suami Pada Ibu Bersalin Terhadap Tingkat Kecemasan Ibu Bersalin Di RB Citra Palembang Tahun 2018}

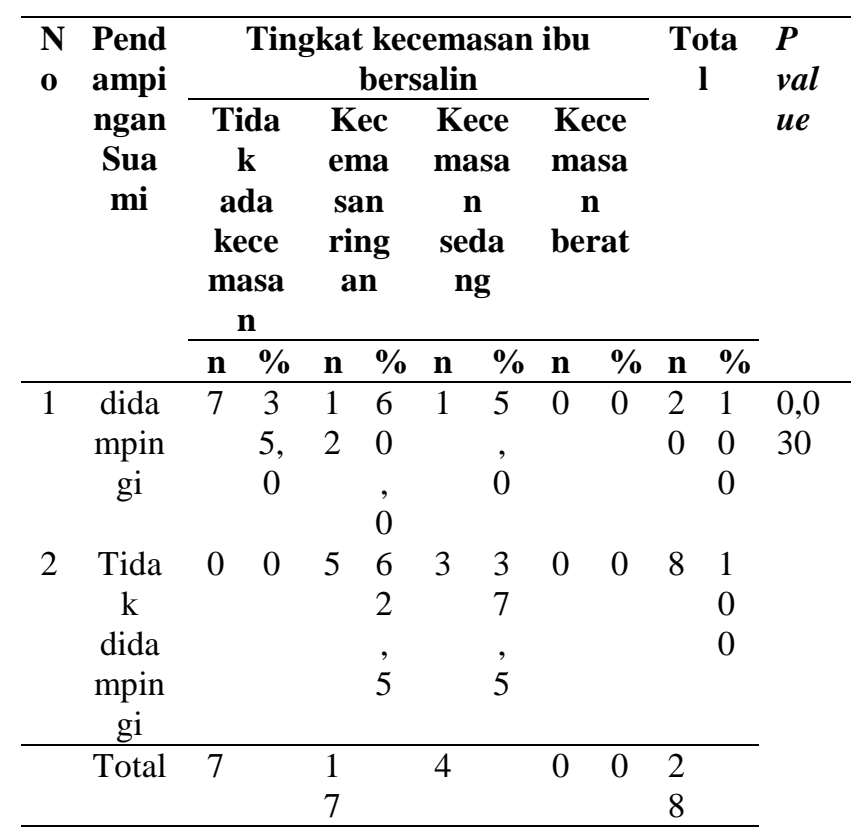

Berdasarkan tabel diatas dapat diketahui dari 20 responden yang didampingi suami dengan tingkat kecemasan ibu bersalin tidak ada kecemasan berjumlah 7 responden $(35,0 \%)$, dengan kecemasan ringan 12 responden $(60,0 \%)$, sedangkan yang mengalami kecemasan sedang 1 responden $(5,0 \%)$ dan kecemasan berat tidak ada.Dari hasil uji Chi-Square diperoleh $p$ value $(0,030)<(0,05)$ yang artinya ada hubungan yang bermakna antara pendampingan suami dengan tingkat kecemasan ibu bersalin. Dengan demikian hipotesis yang menyatakan bahwa ada hubungan pendampingan suami dalam proses persalinan terhadap tingkat kecemasan ibu bersalin terbukti secara statistik.

\section{PEMBAHASAN}

Pendampingan Suami pada Ibu Bersalin di Rumah Bersalin Citra Palembang.

Berdasarkan hasil penelitian diketahui bahwa pendampingan suami dalam proses persalinan di Rumah Bersalin Citra Tahun
2018 sebagian besar mendapatkan pendampingan suami pada ibu bersalin yang didampingi suami yaitu sebanyak 20 responden $(71,4 \%)$ sedangkan yang tidak didampingan suami yaitu sebanyak 8 responden $(28,6 \%)$.

Sesuai dengan pendapat Rohma (2010) bahwa dukungan yang terus menerus dari seorang pendamping persalinan kepada ibu selama proses persalinan dan melahirkan dapat mempermudah proses persalinan dan melahirkan itu sendiri, mengurangi kebutuhan tindakan medis. Pendampingan suami saat persalinan mempunyai peranan penting bagi ibu karena dapat mempengaruhi psikologis ibu. Kondisi psikologis yang nyaman, rileks dan tenang dapat terbentuk melalui dukungan kasih sayang keluarga. Bentuk dukungan bisa berupa support mental, berbagi pengalaman saat menjalani proses persalinan, atau hal-hal positif lain, sehingga berpengaruh pada kekuatan ibu saat melahirkan bayinya.

Hasil penelitian ini didukung oleh penelitian yang dilakukan oleh Lailia dan Nisa (2014) dengan judul "Pendampingan Suami Terhadap Kelancaran Proses Persalinan Di Bpm Arifin S Surabaya", uji Chi Square didapatkan nilai $\rho=0,000$ dan $\alpha=0,05$. Karena $\rho(0,000)<\alpha(0,05)$, maka hipotesis nihil $\left(\mathrm{H}_{0}\right)$ ditolak yang artinya ada hubungan antara pendampingan suami dengan kelancaran proses persalinan.

Berdasarkan hasil penelitian, teori dan penelitian terkait bahwa ada hubungan pendampingan suami dalam proses persalinan. Hal ini menunjukkan pendampingan suami saat persalinan mempunyai peranan penting bagi ibu karena dapat mempengaruhi psikologis ibu. Kondisi psikologis yang nyaman, rileks dan tenang dapat terbentuk melalui dukungan kasih sayang keluarga. Bentuk dukungan bisa berupa support mental, berbagi pengalaman saat menjalani proses persalinan, atau hal-hal positif lain, sehingga berpengaruh pada kekuatan ibu saat melahirkan bayinya dan juga dapat memberi dorongan dan keyakinan pada ibu selama proses persalinan 
berlangsung dan membantu ibu untuk menciptakan suasana nyaman dalam ruang bersalin.

Tingkat Kecemasan Ibu Bersalin Di Rumah Bersalin Citra Palembang. Hasil penelitian diketahui bahwa tingkat kecemasan ibu bersalin yang mengalami kecemasan ringan 17 responden $(60,7 \%)$ tidak ada kecemasan 7 responden $(25,0 \% \%)$, kecemasan sedang 4 responden $(14,3 \%)$, sedangkan yang mengalami kecemasan berat tidak ada.

Menurut Musbikin, 2005. Secara psikologis, istri sangat membutuhkan pendampingan suami selama proses persalinan. Proses persalinan merupakan masa yang cukup berat bagi ibu, dimana ibu membutuhkan dukungan dan pendampingan suami dalam proses persalinan sampai melahirkan dengan aman dan nyaman. Kehadiran seorang pendamping yang suportif dapat membantu mengurangi kecemasan.

Menurut Fraser (2009) selama persalinan, pendamping tersebut dapat terus menemani ibu, berjalan - jalan dengannya jika ia dapat berjalan terutama diawal persalinan, mendukung keputusannya. Tindakan ini diduga mempunyai efek yang positif baik secara emosional maupun fisilogis terhadap ibu dan janin, sehingga ibu dan janin memerlukan sedikit medikasi dan intervensi bahkan persalinan dapat berlangsung dengan singkat.

Hasil penelitian ini sejalan dengan penelitian yang dilakukan oleh Nelisa,2013 dengan judul "Hubungan Pendampingan Suami Terhadap Tingkat Kecemasan Ibu Pada Fase Aktif Kala I Proses Persalinan Normal Di Ruang Bersalin RSUD Kendal”, responden yang mengalami cemas berat sebanyak 13 orang $(27,1 \%)$, sedangkan responden yang mengalami cemas sedang sebanyak 17 orang $(35,4 \%)$, dan responden yang mengalami cemas ringan sebanyak 18 orang $(37,5 \%)$.

Penelitian ini juga sejalan dengan penelitian yang dilakukan oleh Mukhoirotin dan Zulfa Khusniyah, dengan judul "Pengaruh Pendampingan Suami Terhadap
Kecemasan Ibu Pada Proses Persalinan Kala I", bahwa sebagian besar responden mengalami penurunan kecemasan yaitu kecemasan ringan sebanyak 4 (40\%) responden dan tidak mengalami kecemasan sebanyak $5(50 \%)$ responden. Sedangkan yang mengalami peningkatan kecemasan menjadi cemas sedang sebanyak 1 (10\%) responden.Hal ini sebagaimana dikemukakan oleh Suryabrata (2008) bahwa tingkat kecemasan tiap-tiap orang berbeda-beda meskipun yang dihadapi sama, hal ini faktor yang mempengaruhi diantaranya pemahaman diri, kematangan, dan pemahaman dalam menghadapi tantangan.

Berdasarkan hasil penelitian, teori dan penelitian terkait maka peneliti berasumsi bahwa tingkat kecemasan ringan lebih banyak, hal ini dikarenakan ibu yang bersalin rata-rata didampingi oleh suami saat proses persalinan sehingga kecemasan yang dialami ibu dalam menghadapi proses bersalin menjadi berkurang. Hal ini juga berdampak pada psikologi ibu saat bersalin yang menyebabkan ibu merasa nyaman dan aman didekat suami.

Hubungan Pendampingan Suami Dalam Proses Persalinan Terhadap Tingkat Kecemasan Ibu Bersalin Di Rumah Bersalin Citra Palembang. Hasil analisis hubungan antara pendampingan suami pada ibu bersalin terhadap tingkat kecemasan ibu bersalin dari 20 responden yang didampingi suami dengan tingkat kecemasan ibu bersalin tidak ada kecemasan berjumlah 7 responden (35,0 \%), dengan kecemasan ringan 12 responden $(60,0 \%)$, sedangkan yang mengalami kecemasan sedang 1 responden $(5,0 \%)$ dan kecemasan berat tidak ada. Dari hasil uji Chi-Square diperoleh $p$ value $(0,030)<(0,05)$ yang artinya ada hubungan yang bermakna antara pendampingan suami pada ibu bersalin dengan tingkat kecemasan ibu bersalin.

Hal ini sesuai dengan pendapat yang dikemukakan oleh Simkin dkk, (2005) jika proses persalinannya tidak didampingi biasanya ibu bersalin ini akan merasa takut, cemas, merasa tidak aman dan nyaman 
sampai akhirnya dia akan merasa putus asa karena tidak ada yang memberikan semangat, sehingga timbul perasaan tegang. Hal ini akan menghambat proses persalinan yang akibatnya stres pada ibu dan bayi dapat terjadi, sehingga persalinan menjadi tidak lancar.

Ini sesuai dengan teori Indrayani (2013) yang mengatakan bahwa kehadiran seorang pendamping persalinan secara terus menerus akan membawa dampak yang baik pada proses persalinan karena dapat memberikan rasa aman, nyaman dan semangat serta dukungan emosional yang juga dapat membesarkan hati ibu, mengurangi rasa sakit dan mempercepat proses persalinan.

Sesuai dengan pendapat yang dikemukakan oleh Penny Simkin dan Ruth Ancheta (2005) bahwa pendamping persalinan bukan merupakan faktor internal, tetapi secara tidak langsung sangat berpengaruh terhadap psikis ibu sehingga dapat memberikan ketentraman pada hati ibu. Jika selama proses persalinan ibu tidak ada dukungan dan semangat dari pendamping maka waktu persalinan dapat berjalan lama dan jika sudah melebihi garis waspada maka dapat berpengaruh juga bagi keselamatan bayi.

Hasil penelitian ini juga sejalan dengan penelitian yang dilakukan oleh Primasnia (2012) dengan judul "Hubungan Pendampingan Suami Dengan Tingkat Kecemasan Ibu Primigravida Dalam Menghadapi Proses Persalinan Kala I Di Rumah Bersalin Wilayah Kota Ungaran Tahun 2012", Hasil analisis menggunakan Chi Square didapatkan bahwa $p$ value $(0,007)<a(0,05)$. Hal ini menunjukkan bahwa ada hubungan yang signifikan antara pendampingan suami dengan tingkat kecemasan ibu terbukti.

Berdasarkan hasil penelitian, teori dan penelitian terkait maka peneliti berasumsi bahwa kehadiran suami atau pasangan sebagai pendamping persalinan sangat dianjurkan untuk mendampingi ibu selama persalinan, karena pendekatan langsung dapat mendorong komunikasi diantara pasangan sehingga dapat mengatasi semua kekhawatiran dan kecemasan yang muncul pada ibu selama proses persalinan, sehingga dapat mengatasi stress. Dengan kehadiran suami di samping ibu selama proses persalinan ibu akan merasa lebih tenang dan nyaman, ibu merasakan suami ikut menanggung beban dirinya, ibu dapat mengalihkan perasaan cemas yang muncul dengan berkomunikasi dengan suami, ibu merasakan mendapatkan semangat dan rasa percaya diri dari kehadiran suami di sampingnya selama proses persalinan.

\section{SIMPULAN}

Dari hasil penelitian yang telah dilakukan di Rumah Bersalin Citra Palembang Kelurahan Lebong Siarang dapat disimpulkan bahwa :

1. Distribusi frekuensi pendampingan suami pada ibu bersalin yang didampingi suami yaitu sebanyak 20 responden $(71,4 \%)$ sedangkan yang tidak didampingan suami yaitu sebanyak 8 responden $(28,6 \%)$.

2. Distribusi frekuensi tingkat kecemasan ibu bersalin yang tidak mengalami kecemasan 7 responden $(25,0 \%)$, kecemasan ringan 17 responden $(60,7 \%)$ kecemasan sedang 4 responden $(14,3 \%)$, sedangkan yang mengalami kecemasan berat tidak ada.

3. Uji statistic chi-square menyatakan ada hubungan yang bermakna antara pendampingan suami pada ibu bersalin dengan tingkat kecemasan ibu bersalin, dengan $p$ value $(0,030)<(0,05)$ yaitu hipotesis nol ditolak.

\section{SARAN}

1. Bagi Rumah Bersalin Citra Palembang

Rumah sakit sebaiknya lebih memperhatikan kondisi pasien atau ibu yang melakukan proses persalinan dengan meningkatkan keikutsertaan suami dalam pendampingan proses persalinan. Rumah sakit dapat membuat kebijakan tersendiri mengenai pendampingan suami pada ibu bersalin terhadap tingkat kecemasan ibu 
bersalin, atau memberikan pendidikan kesehatan pada suami sebelum ibu melakukan persalinan dengan menyebar leaflet.

2. Bagi STIK Siti KhadijahPalembang

Diharapkan penelitian ini dapat menjadi bahan referensi sebagai informasi yang bermanfaat untuk perkembangan pengetahuan tentang pendampingan suami pada ibu bersalin terhadap tingkat kecemasan ibu bersalin dan dapat juga dilakukan penelitian lebih lanjut untuk mengungkapkan faktor-faktor yang berhubungan dengan tingkat kecemasan ibu bersalin.

3. Bagi Peneliti

Diharapkan penelitian ini dapat ditindak lanjuti dengan menambah faktorfaktor lain diluar penelitian ini seperti faktor ekonomi, faktor sosial dan faktor usia. Diharapkan juga penelitian selanjutnya dapat menambah jumlah sampel yang lebih banyak dan menggunakan metode penelitian yang berbeda.

\section{DAFTAR PUSTAKA}

Agustinus.,2011. Anxiety Disorder. [Accessed 27April http://www.pikirdong.ac.id. 2018].

Asrinah. 2010. Asuhan Kebidanan Masa Persalinan. Yogyakarta : Graha Ilmu.

Depkes RI. 2008. Catatan tentang Perkembangan dalam Praktek Kebidanan. Jakarta : Depkes RI.

Diane and Fraser. 2009. Buku Ajar Bidan Myles. Jakarta: EGC.

Indrayani, Djami. 2013. Asuhan Persalinan dan Bayi Baru Lahir. Jakarta : TIM.

Lailia dan Nisa, 2014. Pendampingan Suami Terhadap Kelancaran Proses Persalinan di BPM Arifin S. Jurnal penelitian UNUSA FKK Prodi DIII Kebidanan, Surabaya

Maitrayani. 2013. Gambaran Kecemasan Ibu Primigravida Dalam Menghadapi Persalinan Di Wilayah Kerja Puskesmas Tanjung Karang Tahun 2013.
Mukhoirotin, Khusniyah. 2010. Pengaruh Pendampingan Suami Terhadap Kecemasan Ibu Pada Proses Persalinan Kala I (Fase Laten- Fase Aktif). website www.journal.unipdu.ac.id diakses pada tanggal 20 Mei 2018.

Mochtar, R. 2007. Sinopsis Obstetri, Obstetri Fisiologi dan Obstetri Patologi. Jakarta : EGC.

Musbikin, I. 2006. Persiapan Menghadapi Persalinan. Jakarta : Mitra Pustaka.

Nelisa, 2013. Hubungan Pendampingan Suami Terhadap Tingkat Kecemasan Ibu Pada Fase Aktif Kala I Proses Persalinan Normal Di Ruang Bersalin RSUD Kendal. Jurnal Keperawatan Maternitas PPNI Volume 2 No 1 Mei 2014. ISSN 2338-2066

Primasnia, Pevi. 2012. Hubungan Pendampingan Suami Dengan Tingkat Kecemasan Ibu Primigravida Dalam Menghadapi Proses Persalinan Kala I Di Rumah Bersalin Wilayah Kota Ungaran. Jurnal Penelitian Mahasiwa Prodi SI Keperawatan STIKES Telogorejo. Semarang

Rohma, Nikmatur. 2010. Pendidikan Prenatal Upaya Promosi Kesehatan Bagi Ibu Hamil. Jakarta : Gramata Publishing.

Saifudin, AB. 2009. Ilmu Bedah kebidanan. Jakarta:Yayasan Bina Pustaka.

Simkin, Ancheta. 2005. Buku

SakuPersalinan.Jakarta: EGC

Sodiqoh, Eva Raisa. 2014. Perbedaan Tingkat Kecemasan Dalam Menghadapi Persalinan Antara Primigravida Dan Multigravida. Jurnal Berkala Epidemiologi, Volume 2 Nomor1, Januari2014, hlm.141-150. FK.Universitas Airlangga. Surabaya

Sumarah, dkk. 2008. Perawatan Ibu Bersalin. Yogyakarta : Fitramaya. 